\title{
PENGARUH LEBAR SUDUT MANGKOK TERHADAP UNJUK KERJA TURBIN KINETIK
}

\author{
Ujiburrahman ${ }^{1}$, Rudy Soenoko, Moch. Agus Choiron \\ Program Studi Magister Teknik Mesin, Jurusan Teknik Mesin, Universitas Brawijaya, \\ Jl. Veteran Malang, Ketawanggede, Kec. Lowokwaru, Kota Malang, Jawa Timur 65145 \\ e-mail: ${ }^{1}$ ujienergy@student.ub.ac.id
}

\begin{abstract}
Power and efficiency are parameters that show the performance of a kinetic turbine. Previous studies have shown various factors such as flowrate, dimensions and geometry of kinetic turbines are variables that affect the magnitude of power and efficiency. In an effort to improve the performance of kinetic turbines it takes a deep understanding of the factors that influence it. Therefore the purpose of this study was to determine the effect of width variations of bowl blades on kinetic turbine performance. The method used in this study was real experimental on a laboratory scale. Tests were carried out on vertical shaft kinetic turbines with blade width variations of $8 \mathrm{~cm}, 9 \mathrm{~cm}$ and $10 \mathrm{~cm}$. Each turbine is tested on variations of water discharge $45 \mathrm{~m}^{3} / \mathrm{h}, 50 \mathrm{~m}^{3} / \mathrm{h}, 55 \mathrm{~m}^{3} / \mathrm{h}, 60 \mathrm{~m}^{3} / \mathrm{h}$ and $65 \mathrm{~m}^{3} / \mathrm{h}$ and in rotation of $80 \mathrm{rpm}$. The results showed that the width of the bowl affected the performance of the kinetic turbine where the width of the $10 \mathrm{~cm}$ bowl blade had a higher performance than the width of the bowl blade $8 \mathrm{~cm}$ and $9 \mathrm{~cm}$. The highest performance of kinetic turbines in the variation of the width of the $10 \mathrm{~cm}$ bowl blade was obtained at discharge conditions of $65 \mathrm{~m}^{3} / \mathrm{h}$. In these conditions the power produced by the kinetic turbine is $\mathbf{1 2 . 9 8}$ Watts and the efficiency is $35.72 \%$.
\end{abstract}

Key words: Kinetic turbine, Blade wide, Turbine power, Turbin efficiency

\begin{abstract}
ABSTRAK
Daya dan efisiensi merupakan parameter-parameter yang menunjukan unjuk kerja sebuah turbin kinetik. Penelitian-penelitian sebelumnya menunjukan berbagai faktor seperti debit aliran, dimensi dan geometri dari turbin kinetik adalah varaibel-variabel yang mempengaruhi besarnya daya dan efisiensi. Dalam upaya meningkatkan unjuk kerja turbin kinetik dibutuhkan pemahaman yang mendalam terhadap faktorfaktor yang mempengaruhinya. Oleh karena itu, tujuan dari penelitian ini adalah untuk mengetahui pengaruh variasi lebar sudu mangkok terhadap unjuk kerja turbin kinetik. Metode yang digunakan dalam penelitian ini adalah eksperimental nyata pada skala laboratorium. Pengujian dilakukan pada turbin kinetik poros vertikal dengan variasi lebar sudu $8 \mathrm{~cm}, 9 \mathrm{~cm}$ dan $10 \mathrm{~cm}$. Setiap turbin diuji pada variasi debit air $45 \mathrm{~m}^{3} / \mathrm{h}, 50 \mathrm{~m}^{3} / \mathrm{h}, 55 \mathrm{~m}^{3} / \mathrm{h}, 60 \mathrm{~m}^{3} / \mathrm{h}$ dan $65 \mathrm{~m}^{3} / \mathrm{h}$ dan putaran $80 \mathrm{rpm}$. Hasil penelitian menunjukan bahwa lebar sudu mangkok mempengaruhi unjuk kerja dari turbin kinetik. Turbin kinetik dengan lebar sudu mangkok $10 \mathrm{~cm}$ menghasilkan daya dan efisiens lebih tinggi dibandingkan turbin kinetik dengan lebar sudu mangkok $8 \mathrm{~cm}$ dan $9 \mathrm{~cm}$. Unjuk kerja tertinggi turbin kinetik pada variasi lebar sudu mangkok $10 \mathrm{~cm}$ diperoleh pada debit $65 \mathrm{~m}^{3} / \mathrm{h}$. Pada kondisi tersebut daya yang dihasilkan oleh turbin kinetik adalah 12,98 Watt dan efisiensinya 35,72\%.
\end{abstract}

Kata kunci : turbin kinetik, lebar sudu, daya turbin, efisiensi turbin

\section{PENDAHULUAN}

Perkembangan teknologi menjadikan energi sebagai kebutuhan mendasar dalam mobilitas kegiatan manusia. Diperkirakan kebutuhan terhadap energi terus meningkat sekitar dua sampai tiga kali dalam kurun waktu sepuluh tahun. Seperti diketahui bahwa penyuplai terbanyak terhadap kebutuhan energi saat ini baik di dunia maupun di Indonesia adalah bersumber dari energi fosil. Sementara itu produksi energi fosil khususnya minyak bumi tidak bisa ditingkatkan secara signifikan karena ketersediaannya semakin terbatas. Di sisi lain, penggunaan energi baru terbarukan belum optimal sedangkan potensinya sangat besar.

Salah satu energi terbarukan yang potensial di Indonesia adalah energi air. 
Energi air merupakan sumber energi yang bersih dan ramah lingkungan. Di dunia secara umum pembangunan bendungan tidak begitu sederhana karena tingginya biaya investasi, dampak pada ekosistem dan banyak kendala lainnya telah menjadi penghambat pengembangan pembangkit listrik tenaga air. Kendala yang sama juga terjadi di Indonesia, hal ini dapat dilihat dari fakta bahwa potensi tenaga air untuk PLTA dan PLTMH tersebar di Indonesia dengan total perkiraan sampai 75.000 MW, sementara pemanfaatannya masih sekitar $9 \%$ dari total potensi [5, $6]$.

Kesulitan pembangunan bendungan telah menyebabkan kecenderungan pemanfaatan energi gerak yang dihasilkan langsung dari aliran air untuk pembangkit listrik. Namun karena laju aliran pada umumnya rendah, ada kebutuhan untuk mendisain turbin yang sesuai untuk kecepatan yang relatif rendah tersebut. Salah satu perangkat pembangkit energi yang sesuai saat ini adalah turbin kinetik, turbin jenis ini mampu untuk mengkonversi potensi energi yang tersimpan dalam aliran dengan kecepatan $0,01-2,8 \mathrm{~m} / \mathrm{s}$ menjadi energi listrik $[7,8]$.

Selain sesuai dengan keadaan energi yang tersedia, penggunaan turbin kinetik juga sangat menguntungkan ditinjau dari pengaplikasian praktis karena memiliki bentuk yang sederhana, mudah dibuat dan pemeliharaan. Namun turbin kinetik masih memiliki kekurangan seperti putaran tidak stabil yang menyebabkan daya dan efisiensi yang dihasilkan rendah [12]. Untuk itu banyak penelitian yang telah dilakukan untuk mengetahui berbagai faktor yang mempengaruhi unjuk kerja turbin kinetik.

Fenomena-fenomena yang dijelaskan pada penelitian sebelumnya diantara lain adalah pengaruh jumlah sudu mangkok terhadap unjuk kerja turbin kinetik [8, 9, 10]. Hasil yang diperoleh menujukan semakin banyak jumlah sudu maka unjuk kerja dari turbin kinetik akan meningkat. Bertambah panjangnya sudu dan besar debit aliran pada saluran turbin akan meningkatkan unjuk kerja turbin kinetik [13]. Penelitian ini juga menjelaskan peningkatan unjuk kerja turbin terjadi karena adanya penambahan massa aliran yang menumbuk sudu turbin sehingga gaya tangensial yang dihasilkan meningkat dan gaya tangensial tersebut mempengaruhi torsi, daya dan efisiensi turbin kinetik. Perbedaan sudut input pada sudu mangkok dana sudut sudu mangkok juga berpengaruh terhadap unjuk kerja turbin kinetik [1, 4]. unjuk kerja turbin dengan sudut input sudu mangkok $10^{\circ}$ lebih tinggi daripada $15^{\circ}$ dan $20^{\circ}$. Semakin kecil sudut input sudu mangkok, kelengkungan sudu semakin besar, sehingga semakin besar pula gaya tangesial, torsi, daya dan efisiensinya. Unjuk kerja turbin kinetik maksimum terjadi pada sudut sudu mundur $15^{\circ}$ dibandingkan dengan variasi sudut sudu yang lain.

Pemakaian bentuk sudu yang berbeda juga mempengaruhui karakteristik daya dan efisiensi turbin [2, 14]. Daya maksimum yang dibangkitkan dan efisiensi maksimum turbin dengan sudu mangkok lebih besar dibandingkan dengan turbin dengan sudu setengah silinder. Namun perbedaan yang diperoleh relatif kecil atau cenderung sama. Penelitian tentang pengaruh sudut pengarah aliran terhadap unjuk kerja turbin kinetic [8, 11]. Hasil pengujian menunjukan unjuk kerja teringgi diperoleh pada sudut pengarah aliran yang terbesar yaitu $35^{\circ}$. Secara keseluruhan dalam rentan variasi sudut pengarah yang diuji dalam penelitian, dapat disimpulkan bahwa semakin besar sudut pengarah aliran maka unjuk kerja turbin kinetik semakin baik.

Berdasarkan hasil penelitian-penelitian diatas dapat dikemukakan bahwa 
berbagai faktor seperti debit aliran, dimensi dan geometri dari turbin kinetik adalah varaibel-variabel yang mempengaruhi unjuk kerja dari sebuah turbin kinetik. Dalam upaya meningkatkan unjuk kerja turbin kinetik dibutuhkan pemahaman yang mendalam terhadap faktor-faktor yang mempengaruhinya. Pengggunaan sudu bentuk mangkok dapat memperbesar gaya tangensial yang akan meningkatkan unjuk kerja turbin kinetik. Sementara itu unjuk kerja turbin kinetik jenis sudu mangkok itu sendiri dapat ditingkatkan dengan menambah masa aliran air yang menumbuk sudu turbin. Oleh karena itu dalam penelitian ini akan diuji atau didemonstrasikan pengaruh variasi lebar sudu mangkok terhadap unjuk kerja turbin kinetik. Penambahan ukuran lebar sudu mangkok diharapkan dapat memperbesar masa aliran air yang menumbuk sudu kemudian meningkatkan nilai daya dan efisiensi dari turbin kinetik.

Tujuan dari penelitian ini adalah untuk mengetahui pengaruh variasi lebar sudu mangkok terhadap unjuk kerja turbin kinetik poros vertikal.

\section{METODE PENELITIAN}

Berdasarkan Gambar 1, langkahlangkah dalam penelitian ini dapat diuraikan sebagai berikut. Rumusan masalah dan hipotesis didapatkan dari hasil kajian terhadap literatur yang tersedia khususnya jurnal elektronik. Berdasarkan penelitian-penelitian sebelumnya diperoleh bahwa parameter daya dan efisiensi merupakan tolak ukur dari unjuk kerja turbin kinetik. Dalam upaya meningkatkan unjuk kerja turbin kinetik dibutuhkan pemahaman yang rinci terhadap variabel-variabel yang mempengaruhinya. Oleh karena itu masalah dalam penelitian adalah bagaimana pengaruh variabel bebas yaitu lebar sudu terhadap variabel terikat yaitu unjuk kerja turbin kinetik.

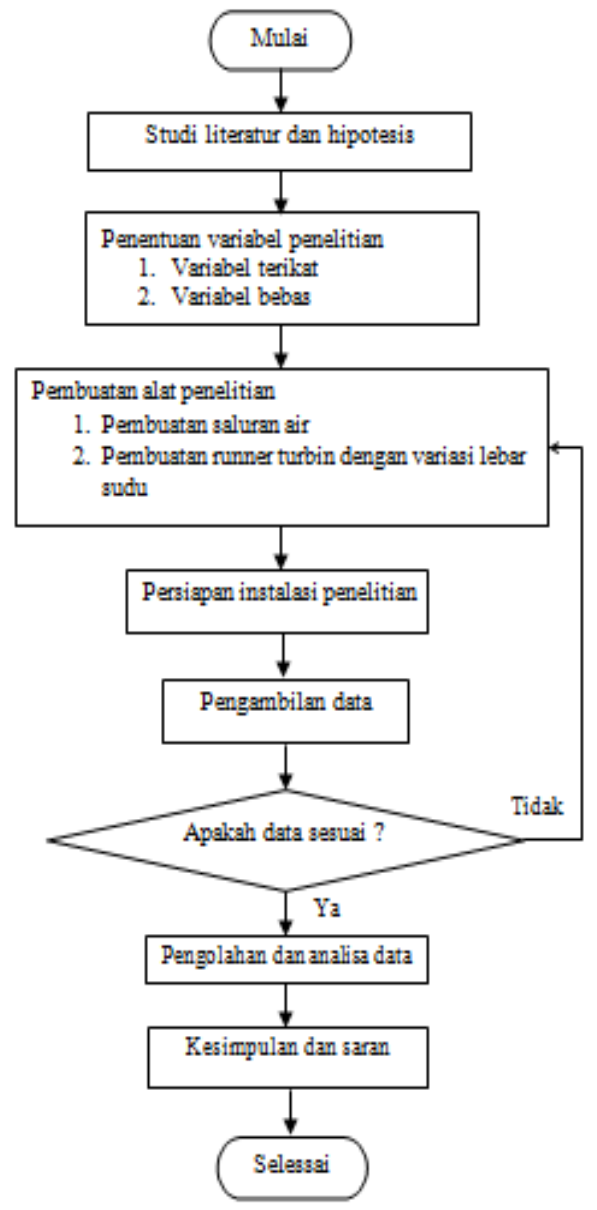

Gambar 1. Diagram alir penelitian turbin kinetik 
Berdasarkan Gambar 1, langkahlangkah dalam penelitian ini dapat diuraikan sebagai berikut. Rumusan masalah dan hipotesis didapatkan dari hasil kajian terhadap literatur yang tersedia khususnya jurnal elektronik. Berdasarkan penelitian-penelitian sebelumnya diperoleh bahwa parameter daya dan efisiensi merupakan tolak ukur dari unjuk kerja turbin kinetik. Dalam upaya meningkatkan unjuk kerja turbin kinetik dibutuhkan pemahaman yang rinci terhadap variabel-variabel yang mempengaruhinya. Oleh karena itu masalah dalam penelitian adalah bagaiman pengaruh variabel bebas yaitu lebar sudu terhadap variabel terikat yaitu unjuk kerja turbin kinetik.

Variabel dalam penelitian ini terdiri atas variabel terikat yaitu daya dan efisiensi turbin, variabel bebas yakni debit air dan lebar sudu beserta variabel kontrol yang mencakup putaran, dimensi dan geometri runner turbin kinetik. Langkah selanjutnya adalah pembuatan alat, instalasi penelitian menggunakan standar instalsi turbin kinetik di laboraturium fluida jurusan teknik mesin Universitas Brawijaya. Saluran air terbuat dari papan kayu dengan tebal $5 \mathrm{~cm}$. Runner turbin terdiri atas poros berdiameter $3 \mathrm{~cm}$, cakram berdiameter $11 \mathrm{~cm}$ dan sudu-sudu berjumlah 8 bilah yang terbuat dari bahan akrilik. Adapun dimensi saluran dan turbin secara rinci dapat dilihat pada gambar 2 dan gambar 3.

Selanjutnya adalah memasang seluruh instalasi peralatan yang dibutuhkan dalam pengambilan data. Hal yang terpenting dalam proses ini adalah memeriksa kondisi-kondisi alat yang akan digunakan agar data yang diambil sesuai dengan tujuan dari penelitian. Pengambilan data dilakukan 3 kali pengulangan untuk setiap perekaman data, tujuanya adalah untuk menghindari adanya kesalahan pembacaan data baik dari alat ataupun dari manusia. Adapun langkah-langkah pengambilan data adalah yang dilakukan adalah (1) Mengatur debit aliran dengan cara memutar kran sesuai dengan variasi debit yang direncanakan. (2) Mengukur putaran poros turbin dengan beban yang diberikan secara pelan-pelan dengan cara memutar tuas penyetel beban gaya sampai memenuhi nilai putaran yang telah ditentukan yaitu 80 rpm. (3) Mencatat data gaya (F) dan debit (Q) pada setiap pengujian turbin dengan variasi lebar sudu. Melakukan tiga kali pengulangan pada setiap variabel yang divariasikan. Mengulang langkah 1 sampai dengan ke 4 untuk setiap variasi yang telah direncanakan.

Jika tidak terjadi kesalahan pada data hasil pengujian maka akan diolah dan dianalisa untuk di interpretasikan. Sebaliknya jika terjadi kesalahan pada data hasil pengujian maka proses penelitian akan diulang dari tahap pembuatan alat. Interpretasi hasil penelitian ditampilkan dalam bentuk grafik kemudian berdasarkan grafik tersebut akan dibahas fenomena hubungan antara variabel-variabel dalam penelitian dan langkah terakhir adalah menyajikan kesimpulan.

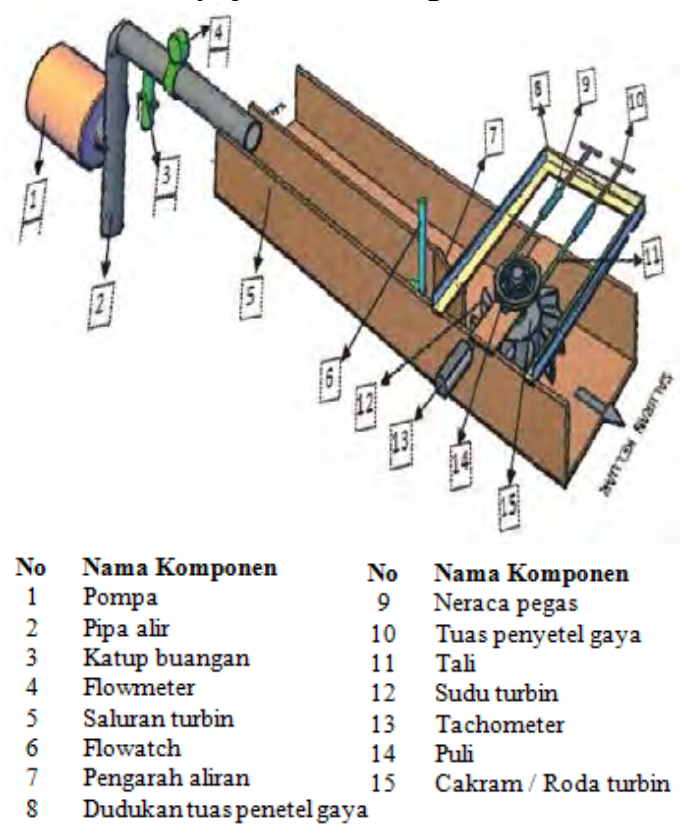

Gambar 2. Skematik instalasi pengujian turbin kinetik 


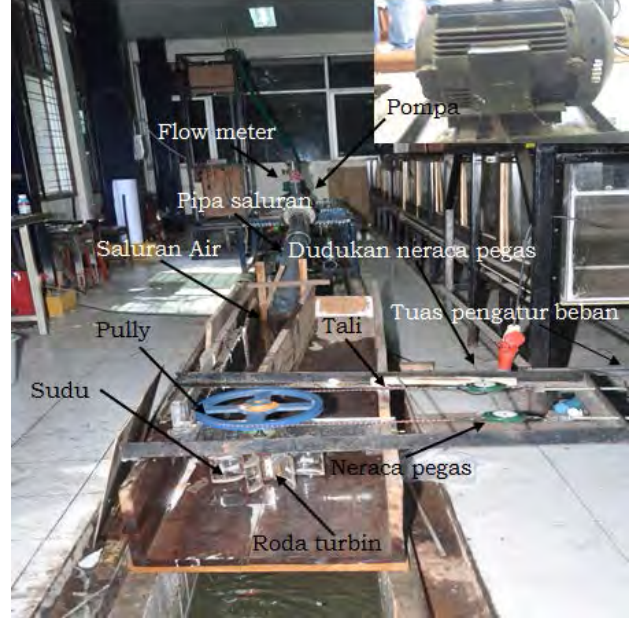

Gambar 3. Dokumentasi instalasi pengujian turbin kinetik

\section{HASIL dan PEMBAHASAN}

Bagian ini memuat pembahasan berdasarkan pada data yang diperoleh dari hasil pengujian dan pengolahan data yang telah dilakukan. Interpretasi hasil dimuat dalam bentuk grafik yang mencakup hubungan antara variabelvariabel peneltian seperti daya turbin, efisiensi turbin dan debit air.

Grafik pada gambar 5 memperlihatkan daya turbin semakin meningkat seiring dengan bertambahnya debit air yang diberikan. Setiap turbin dengan variasi lebar sudu $8 \mathrm{~cm}, 9 \mathrm{~cm}$ dan $10 \mathrm{~cm}$ memeproleh daya minimum dan maksimum pada kondisi debit air yang sama. Daya terbesar untuk turbin dengan variasi lebar sudu $8 \mathrm{~cm}$ diperoleh pada debit aliran $65 \mathrm{~m}^{3} / \mathrm{h}$ yaitu sebesar 6,70 Watt dan daya terkecil pada debit aliran $45 \mathrm{~m}^{3} / \mathrm{h}$ yakni 4,19 Watt. Sedangkan daya tertinggi untuk turbin dengan lebar sudu $9 \mathrm{~cm}$ diperoleh pada debit air $65 \mathrm{~m}^{3} / \mathrm{h}$ yaitu sebesar 10,05 Watt dan daya terendah pada debit air $45 \mathrm{~m}^{3} / \mathrm{h}$ yakni 4,61 Watt.
Sementar itu daya maksimum untuk turbin dengan lebar sudu $10 \mathrm{~cm}$ juga terdapat pada debit air $65 \mathrm{~m}^{3} / \mathrm{h}$ yaitu sebesar 12,98 Watt dan daya minimum pada debit air $45 \mathrm{~m}^{3} / \mathrm{h}$ yakni 5,02 Watt.

Secara keseluruhan dari tiga variasi lebar sudu yang diuji, daya tertinggi diperoleh pada turbin dengan lebar sudu $10 \mathrm{~cm}$, diikuti turbin dengan variasi lebar $9 \mathrm{~cm}$ dan daya terendah diperoleh pada turbin dengan lebar sudu $8 \mathrm{~cm}$. Pada skala dimensi sudu yang diuji dapat dikatakan bahwa semakin besar lebar sudu maka daya turbin akan meningkat pula. Pada nilai debit aliran yang sama lebar sudu yang lebih besar menghasilkan daya yang lebih tinggi. Hal ini menunjukkan energi potensial dari aliran air dapat dimanfaatkan lebih banyak pada turbin dengan variasi lebar sudu yang lebih besar. Secara teoritis besarnya energi potensial air bergantung pada nilai kecepatan dan masa aliran, tentu saja pada debit air yang sama kecepatan aliran juag sama. Oleh karena itu, energi potensial yang dimanfaatkan pada fenomena ini bukan dari kecepatan melainkan penambahan masa aliran yang menumbuk sudu disebabkan luasan sudu lebih besar.

Hubungan debit air dan daya turbin pada setiap variasi lebar sudu memperlihatkan pola yang sama, secara keseluruhan meningkatnya debit air akan meiningkatkan daya turbin. Fenomena ini bisa dipahami karena pada dasarnya daya turbin merupakan daya yang diperoleh dari kecepatan aliran dan massa aliran air yang dikonversi ke putaran poros oleh sudusudu turbin. Masa aliran yang bertambah memperbesar momentum aliran yang menumbuk sudu-sudu turbin. Karena itu ada pertambahan gaya yang menyebabkan torsi meningkat.

Gambar 6 menunjukkan untuk setiap debit yang diuji pada masing-masing turbin diperoleh efisiensi turbin yang lebih tinggi pada variasi lebar sudu 
yang lebih besar. Efisiensi maksimum dan minimum pada masing-masing turbin diperoleh pada kondisi debit air yang berbeda. Pada turbin dengan variasi lebar sudu $8 \mathrm{~cm}$ efisiensi turbin terus menurun seiring dengan naiknya debit air yang diberikan. Efisiensi paling tinggi berada pada debit air 45 $\mathrm{m}^{3} / \mathrm{h}$ yaitu sebesar $22,22 \%$ dan efisiensi paling rendah pada debit air $65 \mathrm{~m}^{3} / \mathrm{h}$ yakni 18,44 \%. Sedangkan untuk turbin dengan variasi lebar sudu $10 \mathrm{~cm}$ memperlihatkan hal yang sebaliknya yaitu efisiensi turbin semakin meningkat dengan adanya penambahan debit air. Efisiensi terbesar terdapat pada debit air $65 \mathrm{~m}^{3} / \mathrm{h}$ yaitu sebesar $35,72 \%$ dan efisiensi terkecil pada debit air $45 \mathrm{~m}^{3} / \mathrm{h}$ yakni 26,67 \%. Sementar itu untuk turbin dengan variasi lebar sudu $9 \mathrm{~cm}$ menunjukan fenomena yang berbeda dari dua variasi lainya. Terjadi kenaikan efisiensi turbin dari nilai minumu pada debit air 45 $\mathrm{m}^{3} / \mathrm{h}$ yakni $8,440 \%$ dan mencapai nilai maksimum pada debit air $55 \mathrm{~m}^{3} / \mathrm{h}$ yaitu sebesar 24,45 \% kemudian efisiensi menurun seiring naiknya debit air.

Efisiensi maksimum terjadi pada lebar sudu $10 \mathrm{~cm}$, dikuti variasi lebar $9 \mathrm{~cm}$ dan daya terendah diperoleh pada lebar sudu $8 \mathrm{~cm}$. Dengan kata lain hasil penelitian menunjukan semakin besar lebar sudu maka daya turbin akan meningkat pula. Pada nilai debit aliran yang sama turbin dengan lebar sudu yang lebih besar menghasilkan efisiensi yang lebih tinggi. Hali ini terjadi karena adanya peningkatan daya turbin pada daya air yang sama. Adanya energi potensial dari aliran air dapat dimanfaatkan lebih banyak pada turbin dengan lebar sudu yang lebih besar. Secara teoritis efisiensi turbin merupakan perbandingan antara daya turbin dengan dengan daya potensial air yang tersedia. Karena itu efisiensi yang lebih tinggi pada turbin dengan variasi lebar sudu yang lebih besar dapat dipahmi karena pada bagian sebelumnya daya turbin yang lebih tinggi juga didapatkan pada turbin dengan variasi lebar sudu yang lebih besar.

Hubungan atara debit air dan efisiensi turbin memperlihatkan pola yang berbeda pada masing-masing turbin dengan variasi lebar sudu. Fenomena ini terjadi karena Kondisi aliran yang berada pada saluran terbuka dimana bertambahnya debit air menyebabkan luasan aliran membesar. karena itu ada kondisi tertentu yang sesuai antara lebar sudu dengan daya air yang tersedia dimana kondisi itu akan menghasilkan efisiensi turbin yang maksimum.

Pada gambar 5 grafik menunjukkan perpotongan yang artinya bahwa daya yang dihasilkan setiap turbin relatif sama pada debit air yang paling rendah pada penelitian ini. Seperti yang telah dijelaskan bahwa turbin kinetik dengan lebar sudu lebih besar dapat memanfatakan daya air lebih optimal karena masa aliran lebih besar menumbuk sudu. Namun pada saat debit air yang rendah luasan sudu turbin dengan variasi lebar sudu yang lebih besar tidak menerima tumbukan aliran yang penuh. Hal ini menyebabkan gaya tangensial yang diterima oleh masingmasing turbin relatif sama. Meskipun demikian pada kondisi tersebut turbin dengan lebar sudu yang lebih besar tetap memiliki daya yang sedikit lebih tinggi karena menampung masa air yang lebih berat. Dengan demikian pada saat debit air semakin rendah bahkan di bawah range dalam penelitian ini maka selisih daya yang dihasilkan turbin akan terus berkurang.

\section{KESIMPULAN}

Lebar sudu mangkok mempengrauhi unjuk kerja dari turbin kinetik dimana lebar sudu mangkok $10 \mathrm{~cm}$ memiliki unjuk kerja lebih tinggi dari lebar sudu mangkok $9 \mathrm{~cm}$ dan $8 \mathrm{~cm}$. Unjuk kerja tertinggi turbin kinetik pada variasi 
lebar sudu mangkok $10 \mathrm{~cm}$ diperoleh pada debit $65 \mathrm{~m}^{3} / \mathrm{h}$. Pada kondisi tersebut daya dan efisiensi yang dihasilkan oleh turbin kinetik berturutturut adalah 12,98 Watt dan 35,72 \%.

\section{DAFTAR PUSTAKA}

[1] Anam, A. R. Soenoko \& D. Widhiyanuriyawan. 2013. Pengaruh Variasi Sudut Input Sudu Mangkok Terhadap Unjuk kerja Turbin Kinetik. Jurnal Rekayasa Mesin. 4 (3): 199-203

[2] Bono \& Indarto. 2008. Karakteristik Daya Turbin Pelton Mikro dengan Variasi Bentuk Sudu. Seminar Nasional Aplikasi Sains dan Teknologi: 187-196. Yogyakarta: IST AKPRIND.

[3] Brian \& Kirke. 2007. Vertical Kinetik Turbine Optimization. The University of Southern Australia

[4] Irawan. 2012. Pengaruh Variasi Sudut Sudu Mangkok Terhadap Unjuk kerja Turbin Kinetik. Malang: Universitas Brawijaya

[5] Kementrian ESDM RI. 2017. Statistik Ketenagalistrikan Indonesia. Jakarta

[6] Kementrian ESDM RI. 2017. Handbook Energy \& Econimic Statistics Of Indonesia, Jakarta

[7] Lago, L.I. F.L. Ponta, L. Chen. 2010. Advances and Trends in hydrokinetic turbine systems, Energy for sustainable development. 14 (4): 287-296

[8] Maidangkay, A. R. Soenoko, \& S. Wahyudi. 2014. Pengaruh Sudut
Pengaruh Aliran dan Jumlah Sudu Radius Berengsel Luar Roda Tunggal Terhadap Unjuk kerja Turbin Kinetik. Jurnal Rekayasa Mesin. 5 (2): 149-156

[9] Ohoirenan, W. 2012. Pengaruh Variasi Jumlah Sudu Mangkok Terhadap Unjuk kerja Turbin Kinetik Roda Tunggal. Tesis. Tidak dipublikasikan. Malang: Universitas Brawijaya

[10] Pietersz, R. R. Soenoko, \& S. Wahyudi. 2013. Pengaruh Jumlah Sudu Terhadap Optimalisasi Unjuk kerja Turbin Kinetik Roda Tunggal, Jurnal Rekayasa Mesin. 4 (3): 220226

[11] Rusman. 2012. Pengaruh Variasi Sudut Pengarah Aliran Terhadap Unjuk kerja Turbin Kinetik. Malang: Universitas Brawijaya.

[12] Soenoko, R. Rispiningtati, \& D. Sutikno. 2011. Prototype of a Twin Kinetic Turbine Performance as a Rural Electrical Power Generation, Journal of Basic and Applied. 1 (10): 1686-1690

[13] Yani, A. 2012. Pengaruh Variasi Panjang Sudu Mangkok Terhadap Unjuk kerja Turbin Kinetik. Malang: Universitas Brawijaya

[14] Yani, A. Mihdar. \& R. Erianto. 2016. Pengaruh Variasi Bentuk Sudu Terhadap Unjuk kerja Turbin Air Kinetik. Journal teknik mesin Univ. Muhammadiyah Metro (TURBO). 5 (1): 8 - 13 


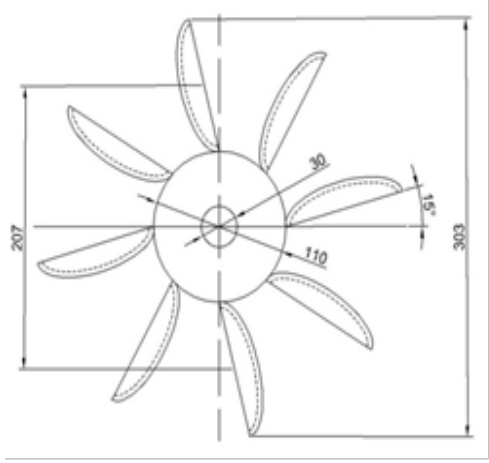

(a)

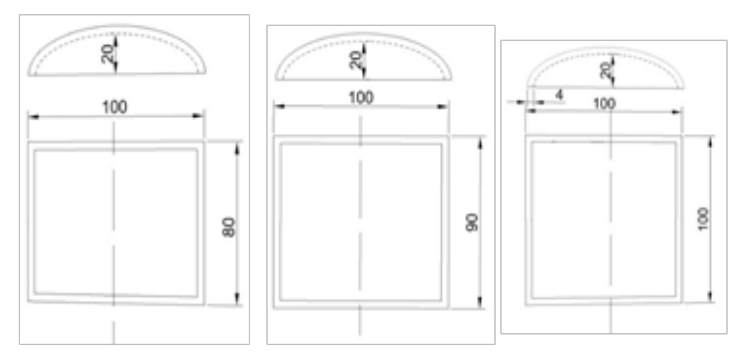

(b)

Gambar 4. Dimensi runner turbin kinetik ditunjukkan oleh gambar (a). Gambar (b) menunjukkan dimensi sudu. (Satuan gambar dalam mili meter)

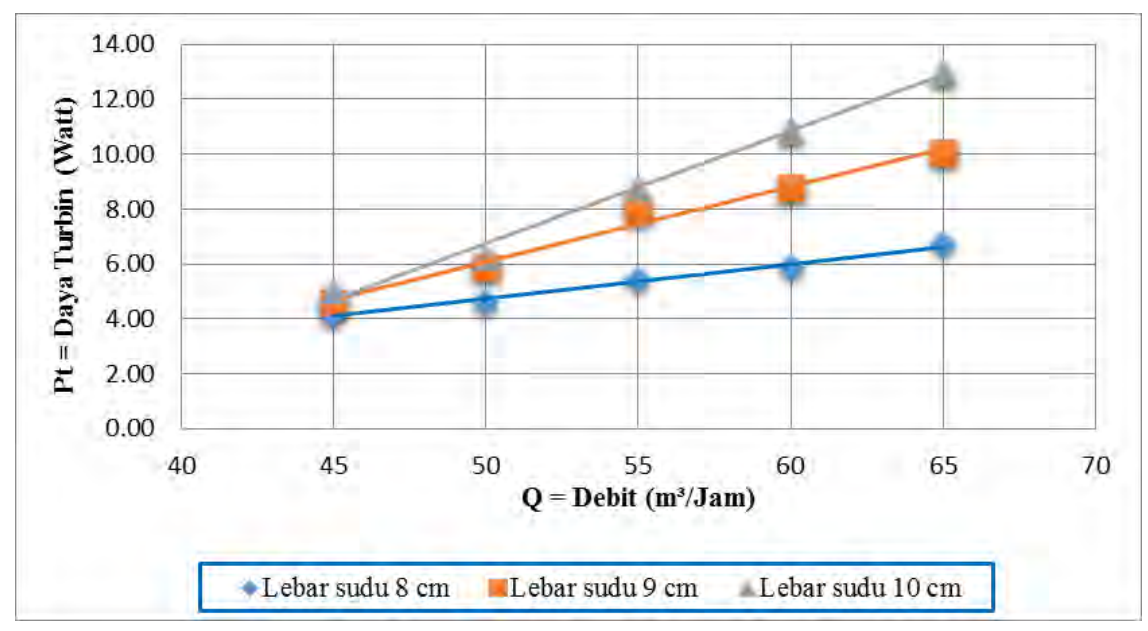

Gambar 5. Grafik hubungan antara debit dan daya pada putaran 80 rpm untuk turbin kinetik dengan variasi lebar sudu $8 \mathrm{~cm}, 9 \mathrm{~cm}$ dan $10 \mathrm{~cm}$

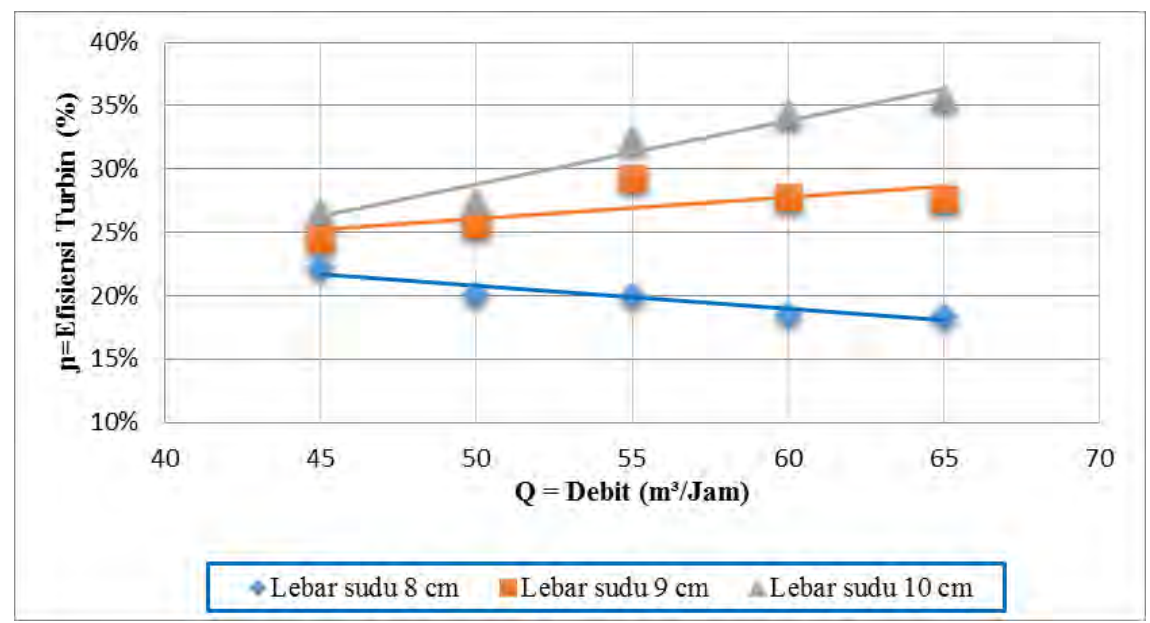

Gambar 6. Grafik hubungan antara debit dan efisiensi pada putaran 80 rpm untuk turbin kinetik dengan lebar sudu $8 \mathrm{~cm}, 9 \mathrm{~cm}$ dan $10 \mathrm{~cm}$ 